\title{
Social Distancing as a Recontextualization of Filipino Values and Catholic Religious Practices: A Response to the COVID-19 Pandemic
}

\author{
Joseph Renus F. Galang ${ }^{1,2}$ (D) . Jose Ma W. Gopez ${ }^{3}$ Ivan Efreaim A. Gozum³ . \\ Philip Joseph D. Sarmiento ${ }^{4}$
}

Accepted: 20 July 2021 / Published online: 30 July 2021

(c) The Author(s), under exclusive licence to Springer Science+Business Media, LLC, part of Springer Nature 2021

\begin{abstract}
This paper investigates Catholic religious practices and Filipino values in the Philippines during the COVID-19 pandemic. It aims to show that religious practices conducted with proper social distancing help in the development of a renewed understanding of Filipino values without contributing to the spread of the virus. This qualitative study makes use of expository writing and content analysis. First, religious practices before the pandemic marked by maximum social interaction are presented. Then, the paper shows religious practices during the pandemic marked by social distancing. Thirdly, the paper looks into how Filipino values are recontextualized in relation to religious practices despite the need for social distancing during the COVID-19 pandemic. Ultimately, the researchers claim that those who participate in religious practices with social distancing do not contribute to the transmission of the virus while still developing a renewed understanding of Filipino values.
\end{abstract}

Keywords Catholic religious practice $\cdot$ Filipino values · COVID-19 · Pandemic Social distancing

\section{Introduction}

\section{Religion as a Social Institution}

Religion is a social institution. French sociologist Émile Durkheim (1912) defined religion as a "unified system of beliefs and practices relative to sacred things". For many, religion is a fundamental dimension of human existence (Koenig, 2012). It teaches about practices and beliefs that serve the needs of a society, leading

Joseph Renus F. Galang

joseph.galang@dlsu.edu.ph

Extended author information available on the last page of the article 
historians to believe that religion is a potent force to effect social change (del Castillo et al., 2021). Religion is something that is present, in one way or another, in all societies.

Religion also fulfils the human need for social interaction. Etymologically, the term "religion" may have come from the Latin religare, to bind (Galang et al., 2018). One of its main purposes, therefore, is to bring people together and form some level of connection and interaction. As human beings, social interaction is necessary in the upkeep of overall health and well-being. Engaging in social interaction, through a social support group, is crucial to physical and psychological health for the elderly (Steptoe et al., 2009). A study found that social interaction through support groups led to reduced levels of depression (Cohen et al., 1986). Another revealed that those who participated in social activities were more likely to report good or very good health status than those who did not participate (Sirven \& Debrand, 2008). Many other studies have posited that belonging to and interacting with a social group help ease the innate burden of being alive.

The human need for social interaction is responded to by religious practices. Religion is one social institution which paves the way for the creation of social groups. Through religious practices conducted in churches, mosques or temples, people are able to engage in social interaction and find some level of social support. Religious practices, mostly communal in nature, vary from festivals and pilgrimages to matrimonial and funerary services to community engagement and outreach services. In religious practices, people are able to find two kinds of connection. First, through religious practices, people are able to connect with the supernatural, or what Durkheim (1912) calls the "sacred". The "sacred" is that which is ideal and transcendent from quotidian existence; it is extraordinary, fear-inducing and awe-inspiring. This is closely similar to what William James describes as the "religious experience", an aggregate of "the feelings, acts...of individual men...so far as they apprehend themselves to stand in relation to what they may consider the Divine" (James, 2004). In here is a human-divine connection, or what can be called a spiritual communion. But what is equally important in the practice of religion is the human-human connection. Humans are naturally relational beings. The relationships formed through religious practice promote a spirit of community, an idea that is commonly preached by almost all religions. It is from these human-human relationships that people draw a lot of strength, will and purpose to continue living. This gives religion its social dimension.

A recent study shows the importance of these human-divine communion, and human-human community (Chan et al., 2019). Initially, the study says that having a belief system, establishing an idea of what is "sacred", can adequately substitute for some functions of human relationships. Essentially, it says that believing in God helps socially disconnected people have a better sense of, or restore their, purpose for living. The feeling of belonging is connected to one's sense of purpose. "When people feel socially connected, their judgments of meaning in life are primarily derived from the highly salient information about their social belongingness" (Chan et al., 2019, p. 4). The same researchers disclaim, however, that though God and religion provide a "substitutive connection", quality human-to-human relationships still remain as the primary source of purpose in living. Religious practices provide 
avenues in establishing and enhancing these human-to-human connections, thereby forming part of a certain religious culture.

\section{Filipino Cultural Values in Context}

In the Philippine context, many cultural values are also strongly linked to religion and religious practices. "Filipino culture affords many traditional values that are deeply consonant with the Christian vision" (Catechism for Filipino Catholics, 1997, \#792). A Filipino value system starts with pagsasarili, or self-reliance, which is the prerequisite for any kind of moral responsibility (Catechism for Filipino Catholics, 1997, \#792;). Pagsasarili is the sense of developing oneself to become responsible (de la Costa, 1971) not only of oneself, but also of others. Pagsasarili, however, is quickly transcended in pakikisama. On the surface, pakikisama is about getting along with others (Catechism for Filipino Catholics, 1997, \#792; National Catechetical Directory of the Philippines, 1985, \#28); more deeply, it is an authentic appreciation of being together, where unity and harmony are evident (Macaraan, 2019). There is also pakikiramay, or empathy, expressed in emotional mutual assistance when in need (Sarmiento, Sibug, Lumanlan, Bonus, \& Samia, 2017). From pakikisama and pakikiramay develop pagkakaisa, or communal oneness (Lanaria, 2014). Above all, the umbrella term for all these Filipino values is pakikipagkapwatao, or being there for the other (Catechism for Filipino Catholics, 1997, \#792; New National Catechetical Directory of the Philippines, 2007, \#40, \#89), practicing solidarity in support of each other (Enriquez, 1992). In pakikipagkapwa-tao is an interpersonal behaviour which sees the other as another self.

Many Filipinos are aware that these values are the proper building blocks to a genuine community. Catholic Filipinos are frequently reminded by priests in homilies about how essential these values are in proclaiming God's kingdom on earth. It is, therefore, through the practice of religion, in the context of the family, that these unique Filipino values are first developed and then honed (Gozum, 2020).

\section{The Emergence of the COVID-19 Pandemic}

The spread of the 2019 coronavirus disease (COVID-19), however, has put a halt to the conduct of these religious practices. Communal religious practices, by their very nature, promote social interaction since they involve mass gatherings. While participation in long-duration mass gatherings is beneficial to well-being (Tewari et al., 2012), joining religious gatherings involving masses of people may do more harm than good to one's health and well-being (Wildman et al., 2020). According to the World Health Organization (WHO) (2020), the coronavirus disease, named COVID-19, is an "infectious disease caused by a newly discovered coronavirus" originating in Wuhan province in China. The virus has not been previously identified in humans (Ocampo \& Yamagishi, 2020). It spreads primarily through salivary droplets or nasal discharges during coughing, sneezing or simple exhaling by an infected person. Any person can be infected when the virus is inhaled if one is within close proximity of an infected person. 
According to the Centers for disease control and prevention (CDC), transmission can also happen when a person touches a contaminated surface and makes contact with the mucous membranes on the face such as on the mouth, on the nose or on the eyes. This is because droplets and discharges which may contain the virus are not able to remain airborne and instead land on the floor and other surfaces surrounding the infected person (Singhal, 2020).

Though there are still debates on how the virus emerged, COVID-19 has been declared as a pandemic and has halted most forms of operations throughout the world, including religious practices. After the expiration of stay-at-home orders, various governments have enforced social distancing, alternatively known as physical distancing, which involves keeping a safe distance of about six feet, or approximately two metres, between oneself and people not from one's household, in both indoor and outdoor spaces. With social distancing in full implementation, naturally, this would mean the inability of religious organizations to perform the usual religious practices which involve mass gatherings of people in small spaces in churches, mosques and temples (Baker et al., 2020).

\section{The Philippine Government's Response to the Pandemic}

The Inter-agency task force (IATF) for the Management of Emerging infectious diseases (EID) in the Philippines convened in January 2020 to make recommendations in addressing the coronavirus pandemic. The IATF is mandated to assist those infected with the virus, minimize the entry of possible carriers in the country, and prevent the local spread of the virus in the country. Living up to its name, the IATF is chaired by the Department of Health, and composes of a majority of agencies which comprise the executive department of the Philippine government, including agriculture, finance, education, foreign affairs, communications, labour and employment, security, social welfare, tourism, transportation and others.

The IATF recommended community quarantine measures to curb the transmission of the virus. On 16 March 2020, the President imposed what was called an "Enhanced community quarantine" (ECQ) in the main island of Luzon, effectively a total lockdown. This involved the restriction of people's movement except from necessity for work and health emergencies. Also, this mandated the temporary closure of what were considered as non-essential business and establishments, including churches. As the quarantines eased about two months after the lockdown, the IATF formulated a "Modified enhanced community quarantine" (MECQ), where church activities are limited to a gathering of 10 persons; then, a "General community quarantine" (GCQ), where venues for religious activities can be filled up to $30 \%$ of their capacity; and finally, a "Modified general community quarantine" (MGCQ), where seating capacity was allowed at $50 \%$. More than a year later, the country saw a surge of COVID-19 cases in April, forcing the government to impose tighter restrictions to control mobility for another two weeks (Jalea, 2021). 


\section{Philippine Catholic Church's Response to the Pandemic}

In an effort to safeguard their members while still fulfilling their spiritual needs, the Catholic Church in the Philippines has religiously followed these government protocols. A circular letter by the Catholic bishops' conference of the Philippines (CBCP) on 16 May 2020 issued recommendations and guidelines for liturgical celebrations amidst the quarantine protocols. The letter said that two ways have "emerged and become effective ministerial channels" (p. 1) during the quarantine: the use of social media through livestreamed and televised liturgy, and the liturgy with the faithful in attendance (Valles, 2020). Later, Church authorities cancelled processions, visits to cemeteries and other religious mass gatherings (Calleja, 2020b). Archbishop Romulo Valles, CBCP President, echoed Pope Francis April 17 homily: "This is the Church in a difficult situation that the Lord is allowing, but the ideal of the Church is always with the people and with the sacraments-always" (Glatz, 2020, n.p.). While the virus has stopped Filipinos from physically going to church, it has brought them new ways of promoting the Filipino values while practicing their faith which can never be taken away from them.

This paper, then, aims to understand the religious practices and Filipino values during the COVID-19 pandemic in the Philippine context. First, the paper presents Filipino religious practices before the COVID-19 pandemic; then, compared to the religious practices during the same pandemic. Finally, the paper looks into how Filipino values are recontextualized in relation to religious practices despite the need for social distancing during the COVID-19 pandemic.

\section{Methodology}

This qualitative study uses expository writing in the form of content analysis as its method. Expository writing is designed to explain a topic to give facts, explain ideas or define conditions to provide deeper insights to readers (Hubbard, 2012). Furthermore, as a method which analyzes data and interprets its meaning, the qualitative content analysis done in this paper involves three methods: preparation, organization, and reporting of results (Elo et al., 2014). In this process, to enhance the integrity of knowledge-building systematic reviews, the researchers made rigorous literature search processes on religion, Filipino values and the COVID-19 pandemic, as transparent as possible (Finfgeld-Connett \& Johnson, 2013). The used documents in this paper were online journal articles downloaded from the world wide web through accessing electronic databases such as SCOPUS, EbscoHost, ProQuest Online, Google Scholar and other sources.

This study analyses values that are deeply embedded in Filipino culture in order to recontextualize them. Culture has both explicit and implicit characters (Nuncio et al., 2016). The explicit characters include the observable behaviours, symbols and rituals, such as the way people dress, the kind of food they eat, the way they express their beliefs. The implicit characteristics include a group of people's underlying values and unwritten norms which guide people as to how to act appropriately (Miller, 2005). Considering this, even Filipinos who do not observe the health protocols and 
those who do not have the values under analysis in mind are still included in the recontextualization process. This interpretation and recontextualization of Filipino values are not accomplished only through positive evidence, but also by recognizing the negative, even contradicting, realities that permeate Filipino society.

\section{Results \& Discussion}

\section{Filipino Religious Practices before the COVID-19 Pandemic}

According to Vatican News ("Philippine Church releases logo for 500 years of Christianity", 2019), the Philippines has about $81 \%$ of its estimated population of some 100 million identifying themselves as Catholics, considered to be the home to Asia's largest Catholic population. The coming of the Spaniards during the early sixteenth century paved the way to the birth of Christianity in the country (del Castillo, 2015a, 2015b). In fact, each barangay, or village, in the country honours a particular patron saint. In the northern part of the country, millions of devotees of the Black Nazarene flock the feast every $9^{\text {th }}$ of January. The festive celebration is called the traslacion, from the Spanish for transfer, the most massive procession in the country. The miraculous mid-eighteenth-century image of the suffering Christ, a dark-skinned, kneeling Jesus carrying the cross, is usually set in an all-day procession for public adoration brought by millions of barefooted devotees to and from the Minor Basilica of the Black Nazarene in Quiapo, Manila (Aguinaldo, 2002). Based on the numbers recorded from 2004-2014, a significant increase of 4,000\%, from $300,000-12,000,000$ devotees attended the yearly celebration (Guidaben, 2014). Because of the massive attendance in this feast, January 9 is declared as a holiday in the city of Manila, suspending work and classes in both public and private sectors (Aguilar, 2021). Meanwhile, the southern region of the country celebrates the Sinulog festival in honour of the Santo Niño or the Holy Child Jesus every third Sunday of January. This annual religious and cultural festival commemorates the historic background of the Filipinos in becoming Christians through Spanish colonialism from their indigenous animistic beliefs (Reyes, 1985). The recent festival held in 2019 reported at least 1.5 million devotees who joined the foot procession (Mayol \& Mondragon, 2019) wherein all pilgrims repeatedly shout, "Viva Pit Señor!", meaning "Hail Lord, listen to our prayers". These two major religious festivities in the country go along with a nine-day preparation with the celebration of the Holy Eucharist - the novena Masses - with a big crowd awaiting the day of the celebration itself. Thus, the expression of communal faith of the Filipino people is in itself a manifestation of the constant need for social interaction.

The apostolic visits of Roman pontiffs in the country were also venues of social gathering and interaction among the Filipinos. So far, there have been three popes who have visited the Philippines, namely: Paul VI, John Paul II, and Francis. Undoubtedly, all their historic visits attracted public gatherings among Filipino Catholics. The second visit of the late John Paul II as a pope was in January 1995 to celebrate the $10^{\text {th }}$ World Youth Day. During his last day of visit, there were more than four million Filipinos who participated in the Mass of John Paul II (Medina \& 
Antonio, 2014). This visit set the record as the largest papal crowd in history at that time. The coming of Francis to the country in January 2015, in the same place where John Paul II celebrated the Mass, broke the record. A Vatican official mentioned that Pope Francis' Holy Mass in the Philippines surpassed the present record of the largest papal crowd in history, with an estimated 6 to 7 million Filipinos gathering in Manila (Pullella \& Francisco, 2015). Despite the heavy rains, Filipinos managed to stay just to receive the papal blessing. Truly, papal visits, which rarely happen in the life of a Filipino, are social expressions of the communal faith of Filipinos.

Another form of public religious gathering in the country is the celebration of Misa de Gallo and Semana Santa. Misa de Gallo, or Simbang Gabi in Filipino, is an enduring religious tradition in the Philippines as a spiritual preparation for Christmas Day (Pateña, 2018). This famous Filipino pre-Christmas tradition begins on December 16 and ends on December 24, when massive hordes of faithful attend the nine-day dawn Masses. Despite being set in the wee hours of the morning, usually at 4o'clock, both the interiors and exteriors of churches are filled with Filipino Mass-goers, going in as entire families. Simbang Gabi is also recognized by Catholic Filipino communities who are living around the world because this Filipino tradition is a strong indication of the depth of Catholicism among the Filipino people (Mendiola, 2018). Similarly, the Simbang Gabi honours Inang Maria, or Mother Mary, highlighting her contribution in the history of salvation and emphasizes her important virtues in Filipino culture (Carbayas \& del Castillo, 2020). In the Philippines today, the Misa de Gallo is celebrated for the perseverance of a nation in the Christian faith and the preservation of religion in the world.

After the Christmas season, the next most highlighted religious Filipino tradition is the observance of the Semana Santa - the Holy Week (Sarmiento et al., 2017). This occasion is just as special to Filipinos as Christmas is (Thomas, 2017). Semana Sanata is traditionally a solemn occasion and a time for serious atonement in the Philippines. Many Filipinos during Semana Santa observe religious practices as an expression of gratitude to God. Devout Filipino Catholics even go to church the entire Holy Week while observing fasting and abstinence. It begins with the celebration of Palm Sunday that commemorates the triumphant entry of Jesus Christ in Jerusalem, bringing their palaspas, palm fronds, to church to be blessed by the priest during the Mass. Then, they bring the blessed fronds back home with them. After the Palm Sunday celebration, the traditional Pasyon, the uninterrupted reading or chanting of verses about the suffering of Christ, starts, and ends on Holy Wednesday in most places. In some other parts of the country, however, the chanting of the Pasyon extends up to Good Friday, the day commemorating Jesus' burial; those singing believe that they are accompanying the grieving mother of Jesus. Maundy Thursday, the day commemorating Jesus' last supper with his disciples, is mostly celebrated by the Filipino community through Visita Iglesia wherein they visit at least seven churches' altars of repositories, embellished with fresh and beautiful flowers, and the consecrated host as the showpiece. The most striking feature of holy week celebrations in the Philippines is observed every Good Friday. It is one of the holiest days in the country. In the morning, Filipino catholics, mostly barefooted, pray the way of the cross on Good Friday. Some Filipino penitents self-flagellate in public, a form of re-enactment of the suffering and death of Jesus. They whip 
their backs full of blood while others carry heavy wooden crosses along the streets. Provinces such as Pampanga and Nueva Ecija are famous for their flagellants who cover their faces with a white cotton hood with crowned thorns on their heads. Good Friday stages a re-enactment play-Senakulo, from the Spanish cenáculo - that depicts the story of life, passion, and resurrection of Jesus Christ. The dramatization is oftentimes held in a hilly area in the town, sometimes just within the church, where curious tourists could watch (Thomas, 2017). In San Pedro Cutud, a barangay in Pampanga, a popular expression of faith and religiosity happens every three in the afternoon of Good Friday - the ritual of nailing on the cross of some penitents who promise to do a sacrifice for their faith in the hopes of being rewarded by a divine response to their prayers (Tiatco \& Bonifacio-Ramolete, 2008). This is witnessed by thousands of spectators from all over the country, even from abroad. On the evening of Good Friday, faithful gather for the long procession of life-sized statues of the Santo Entierro (dead Christ) and Mater Dolorosa (sorrowful mother) as a preparation for Black Saturday when Christ is buried and entombed. Filipinos spend the day preparing for the night vigil leading up to Easter Sunday-the resurrection of Christ. The holy week celebration in the Philippines is culminated by attending a salubong-literally welcoming - ceremony commemorating how the Blessed Virgin Mary met her son Jesus who has come back to life. This coincides with the Easter Sunday liturgy. The Semana Santa attracts not only Filipinos, but also a good number of tourists around the world to witness this long-standing tradition of the Filipinos (Table 1).

Filipino religious practices are not celebrated alone. Faith, in the Filipino perspective, is more communal than personal. These religious events are manifestations of the Filipino community's faith in God. Social gatherings are inseparable from the faith experiences of Filipinos.

What happens, now, when Filipinos are not allowed to gather to express their faith?

\section{Filipino Religious Practices during the COVID-19 Pandemic}

On 16 March 2020, Philippine President Rodrigo Duterte imposed an enhanced community quarantine in the main island of Luzon to mitigate the spread of the coronavirus. With this, worship places for the diverse religions in the country were forced to close. As a preventive measure, instead of worship places being opened for the public, during the pandemic, religious services were held online (Meza, 2020). Quickly and efficiently, religious activities from the catholic Church, such as Masses, were now streamed through Facebook or YouTube so that the faithful can still attend such activities. These actions, which go towards virtualization and online contacts, are done by the Church because social distancing is required so that the transmission of COVID-19 will be lessened (Sulkowski \& Ignatowski, 2020).

For this reason, the suspension of public gatherings changed the liturgical life of the Catholic Church since the usual physical participation in the church is prohibited (Corpuz \& Sarmiento, 2021). Following this, the faithful are given an option to attend Masses at home by watching online. Even the World Health 


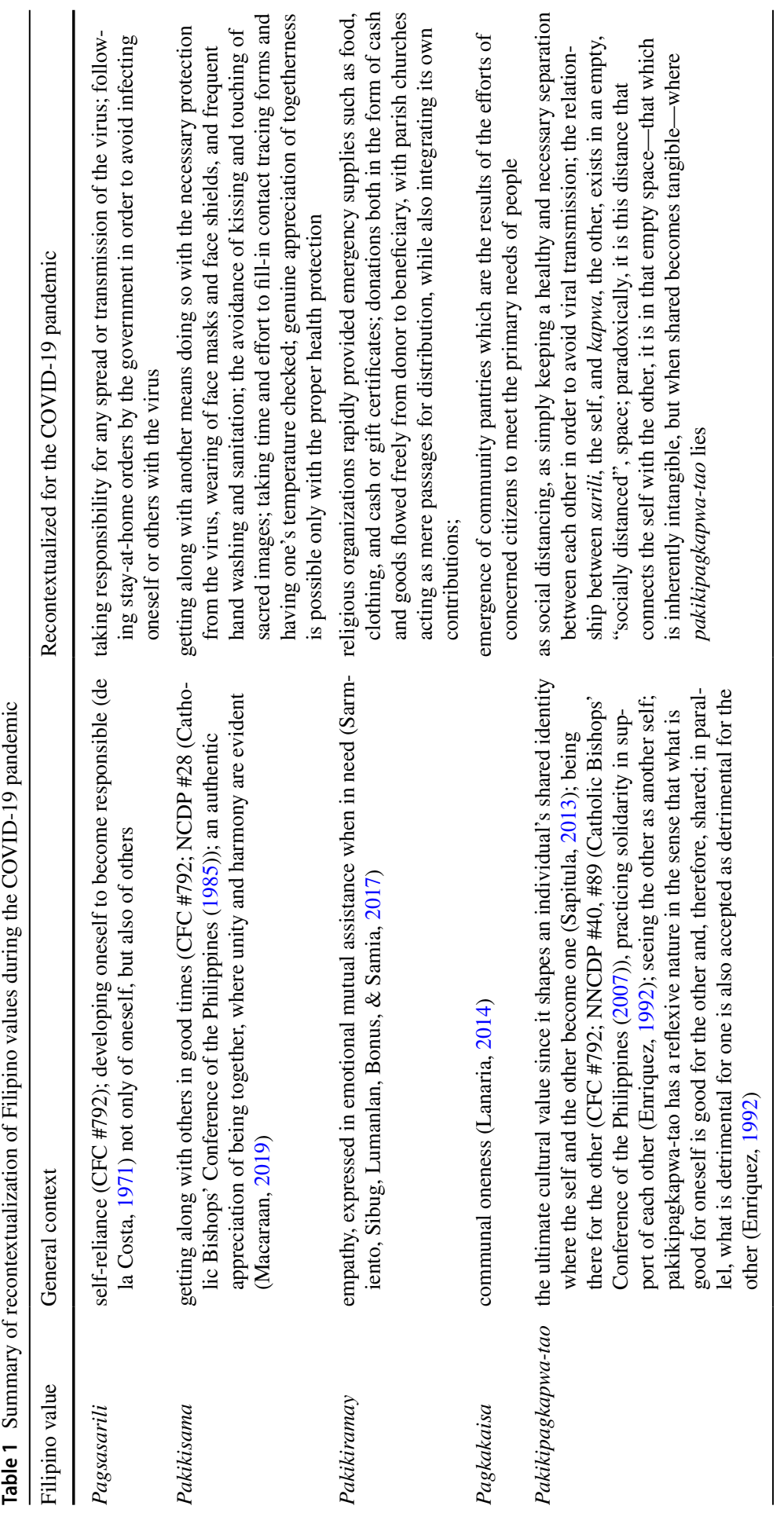


Organization proposed guidelines which require members of the Church to maintain physical distance, hold online celebrations, and prevent touching and kissing devotional or other objects (World Health Organization, 2020). Thus, this shift from physical to virtual celebrations is a collaborative effort for the Church and the government to curb the spread of the virus.

During the ECQ in the country, going outside one's home, unless one is part of the skeletal workforce and healthcare, is strictly prohibited. This setup made one's home as the place of worship since those who attend Masses are just at home participating in the online worship (Corpuz \& Sarmiento, 2021). In fact, Valles proposed recommendations and guidelines on how the liturgical celebrations during the pandemic should be held. Valles (2020) accentuated that during this new setup, the use of social media and rediscovery of the domestic church has been the ways in which the Church can still fulfil the mission of evangelization. As an example, the Holy Father Francis live streamed from the Library of the Apostolic Palace last 7 March 2020 for the praying of the Angelus (Corpuz \& Sarmiento, 2021). Hence, social media has been the primary platform for evangelization and liturgical celebrations during the ECQ.

Holy Week celebrations were also held online. Masses, retreats, and other practices were held virtually. Esmaquel (2020, n.p.) states that "videos of how to make their own palaspas or palm fronds circulated in Catholic social media circles, while families prepared their makeshift altars and priests readied their laptops and webcams". These videos that circulated online showed that the holy week is not an exemption to breach the quarantine protocols. Even the famous Visita Iglesia, the Lenten tradition to visit seven different churches on Maundy Thursday, and Pasyon, the uninterrupted chanting of the passion narrative of Jesus, were held online. In an article published in 2014, Paje (2014, p. 32) reports that "the Visita Iglesia online featured 11 churches during the Lenten Season of 2013 which a devotee could "visit" through short video documentaries uploaded using youtube". The idea that was discussed by Paje years ago regarding a website for visita iglesia became relevant and useful in celebrating the holy week during the ECQ. Several Facebook pages from different parishes and vicariates in the country posted photos of different parishes so that the faithful can visit them virtually. To support this practice, the CBCP launched a website so that, even while staying in the safety of their homes, the Catholic faithful can do a virtual church visit on Holy Thursday (Santos, 2020).

Apart from this, death and burial practices were also changed. Recognizing that death and burial practices are spiritual interventions by the Church, they must be done with strict compliance with the health protocols against COVID-19 (Sarmiento, 2021). Due to the COVID-19 pandemic, the bereaved are to hold wakes for a shorter period of time. Also, the guidelines during the pandemic forced the families of the people who died-or suspectedly died-due to the coronavirus, to cremate the remains of their loved ones (Sarmiento, 2021). This change in practices clearly shows that the Church is sincere in collaborating with the government to lessen the spread of the virus. This is rooted in the willingness of the leaders of the Church so that they can contribute for the greater good during the pandemic (Sulkowski \& Ignatowski, 2020). 
Then, from 16 May 2020-1 June 2020, the government placed some provinces in GCQ and MGCQ. With this, those provinces that are under GCQ can let their churches accept churchgoers up to $30 \%$ of the seating capacity. On the other hand, those provinces that are under MGCQ can let their churches accept churchgoers up to $50 \%$ of the seating capacity. While attending Masses, churchgoers are required to maintain physical distance. Also, it was emphasized that churchgoers should follow the IATF guideline which prohibits the elderly, the young, the sick, and the children since they are outside the allowed age range to go out of their houses (Valles, 2020). Moreover, live streamed and televised Masses are encouraged to be continued so that the faithful will not be urged to go out of their homes just to fulfil their church obligation. Meanwhile, in regard with the priest and lay ministers, the CBCP recommended that they should wash and sanitize their hands before and after each celebration, wear face masks always, practice social distancing in the sanctuary, and limit lectors, altar servers, and choir members to a minimal number (Valles, 2020).

In addition, all church goers must always wear face masks and face shields. Markers should be provided by the church so that the faithful can maintain the allowed distance while seating. Moreover, the CBCP recommends augmenting the schedule of Masses to lessen the number of attendees in each Mass (Valles, 2020). Also, the entry and exit points should be well supervised by ushers so that physical distancing will be maintained. To further supervise the proper protocols at the entry and exit points, thermal scanners, foot baths, and hand sanitizers should be provided. In regards with the offertory and preparation of gifts, the $\mathrm{CBCP}$ recommends that "a deacon (if present) or a server may bring the missal, chalice, paten/ciborium, and cruets of wine and water to the altar, while the priest remains at the chair. (Alternatively, the priest could do this himself.) After the deacon or servers move away, the priest could come to the altar and arrange the items on the altar. The lavabo should be done by the priest alone, without assistance, at the credence table near the altar" (Valles, 2020). For the collection, long-handled baskets could only be acceptable if the ushers can remain at a suitable distance from others (Valles, 2020). If not available, designated boxes or collection points should be provided so that social distancing can be observed.

Apart from these, the Holy Communion will only be distributed on the hand so that the faithful will not remove their face masks while receiving the body of Christ. However, as long as they are in an accepted distance, they are asked to consume the sacramental bread immediately. To ensure the safety of those who will receive communion, the eucharistic ministers should wear face masks and sanitize their hands before distribution of Holy Communion (Valles, 2020). Also, tapes should be placed on the floor to indicate the proper spacing between the people so that they will be properly guided while standing in line. Moreover, holding of hands during the Lord's prayer and shaking of hands during the sign of peace are to be prohibited (Valles, 2020). Lastly, proper disinfection of the place of worship should be done before and after the Mass.

For the rite of baptism, the $\mathrm{CBCP}$ recommends that the attendees inside the church should be limited to immediate family members and to one or two godparents (Valles, 2020). While attending baptism, the people inside the church should always wear face masks and face shields and observe social distancing. Also, 
the baptismal water should be clean and blessed, while the holy oils should be applied, using cotton, on the one being baptized (Valles, 2020). The used cotton with holy oils should be burned immediately after the celebration. As for the rite of confirmation, the confirmation Mass for the year can be foregone except for those who will be married. If this is the case, the parish priest should be the one to administer the sacrament. Apart from this, weddings will be simpler because of the required social distancing. The secondary elements of the wedding ceremony will be foregone. Only the bride and the groom, the parents of the couple, and one set of sponsors are to be present in the ceremony (Valles, 2020). Because confession requires a face-to-face meeting between the confessor and the penitent, it is preferable that they be heard outdoors, where there is better circulation of air and additional space for safe distance (Valles, 2020). Also, it is highly recommended that the Oratio Imperata against COVID-19 be prayed after communion. The Mass in Time of Pandemic, a plea "for God's mercy and gift of strength in the midst of the coronavirus pandemic" (Wooden, 2020), can also be celebrated.

Additionally, since Catholicism in the country is known for festive events, such as fiestas, parishes are asked to not hold any celebration. Instead of processions in which many people attend, images of Jesus, Mary, and saints will have a motorcade. This is done while the faithful prayerfully wait for the motorcades of devotional images pass-by. Some of the events that were affected by the pandemic were the annual re-enactment of the coronation of the blessed Virgin Mary in her title "Virgen De Los Remedios" in the province of Pampanga every September 8 (Manabat, 2020), the annual feast of Our Lady of Penafrancia in Bicol region, and the many feast day celebrations in various villages and towns especially during the month of May. Instead of the usual celebration wherein thousands of devotees attend, these events were streamed on Facebook and broadcasted on TV and radio stations. To add, the simbang gabi and Christmas Eve Mass were live streamed while those who attended physically followed the safety protocols and guidelines released by the CBCP.

Moreover, a more famous feast in the country affected by the pandemic is the feast of the Black Nazarene. This event usually gathers millions of attendees in Manila yearly. For the celebration, the Quiapo Church has instilled a 400-person cap for each of the 15 masses that will take place on the January 9 feast, which means only 6,000 will be able to attend services inside the church (Catholic News Agency 2021). This is the allowed number of attendees because Manila was still under GCQ by then. To aid those who were not able to enter the church, large screens outside the church were displayed. Also, instead of kissing the statue, a practice also known as pahalik, attendees were able to venerate and pray with the statue, which was visible on the church's balcony ("Attendance limited at Black Nazarene Masses in Philippines", 2021). To add, smaller images were suggested to be brought by the attendees instead of the usual large replicas. Even though the feast was still celebrated, the traslacion, the yearly 19-24 h procession, was cancelled.

The following actions by the Catholic Church were done so that the transmission of COVID-19 will be mitigated. However, with this setup, the experience and values that the people gain from attending religious practices might have changed. With 
this, the next part of this paper tackles a recontextualization of Filipino values in religious practices during the COVID-19 pandemic.

\section{Recontextualizing Filipino Values during the COVID-19 Pandemic}

An individual's decision-making regarding their social mobility during the pandemic is highly influenced by cultural traits such as religious practices and values (Deopa \& Forunato, 2020). "[C]ulture is seen as a connection to each individual, and it expresses the collective sense of the behaviour of people which in return this behaviour contributes to spreading or suppressing the COVID-19 virus" (Lagman et al., 2021). So, how can Filipino values and religious practices be understood during the COVID-19 pandemic?

The value of pagsasarili, or self-reliance, was manifested during the early days of the pandemic. When there was little information about the virus and how it was transmitted, Filipinos were quick to follow stay-at-home orders by the government. Through this, Filipinos were, to a certain extent, forced to rely on their ingenuity in terms of satisfying their basic needs, ranging from physical to social. Pagsasarili is also expressed in quarantining at home. In these early days of darkness, Filipinos' religious and spiritual needs were fulfilled through attendance in the Holy Mass live streamed on social media platforms. Pagsasarili is also when the faithful's involvement in the liturgy was transformed from a communal church service to a house church (Corpuz \& Sarmiento, 2021). What was supposed to be a communal celebration in the flesh, in the actual presence of the faithful, turned into a virtual ceremony in the spirit. For the priest, there was no visible congregation; for the congregation, there was only the priest, and a few select individuals such as readers and sacristans. Unusual, but Filipinos carried on, for they recognized that pagsasarili is also the foundation for any moral responsibility (Catechism for Filipino Catholics, 1997, \#792). To practice pagsasarili, therefore, means taking responsibility for any spread or transmission of the virus, and the most morally responsible action to avoid any of this is to stay at home.

Transcending pagsasarili as quarantine protocols relaxed, Filipinos were allowed to go out of their homes, but were frequently reminded to follow minimum health protocols. During the pandemic, pakikisama as getting along with others has been translated into wearing of face masks and face shields, and frequent hand washing and sanitation. Whether in the workplace or in restaurants, one cannot get along with another without the necessary protection from the virus. In church, pakikisama is expressed in the avoidance of kissing and touching of sacred images. Pakikisama is taking time and effort to fill-in contact tracing forms and having one's temperature checked; some parishes have utilized technology such as QR (Quick response) codes in tracking the flow of worshippers. In welcoming the congregation, church administrators have ensured the disinfection of the place of worship. On a higher level, pakikisama is the genuine appreciation of togetherness. Filipinos are a highly sociable people. So, when each person is considered as a potential carrier of the virus, there can be no genuine appreciation of togetherness without the proper health 
protection. One cannot focus on the practice of one's faith if the other is without proper protection.

For Filipinos, getting along means maintaining interpersonal relationship both in good times and in bad; hence, there is pakikiramay, or mutual assistance in various forms. As the quarantine protocols went on, more and more Filipinos became unemployed (de Vera, 2020), with families going hungry. The Filipino value of pakikiramay was evidently at play as various religious organizations rapidly provided emergency supplies such as food, clothing, and cash (Calleja, 2020a). Some relief responses during the pandemic were organized by private individuals, but most were coordinated with the social action centres of parish churches or dioceses. Termed as ayuda, from the Spanish help, donations both in the form of cash and goods flowed freely from donor to beneficiary, with parish churches acting as mere passages for distribution, while also integrating its own contributions. Especially in the midst of a world crisis, the Catholic Church in the Philippines again proved to be a trustworthy agent of human generosity. The spirit of pakikiramay brought both food and hope to the Filipino dining table. Caritas Manila, the social action arm of the Archdiocese of Manila, distributed gift certificates which can be used to buy food and other basic needs (Patinio, 2021). In pakikisama and pakikiramay is pagkakaisa, or communal oneness, in times of plenty and paucity. One concrete example of pagkakaisa was the emergence of community pantries which are the results of the efforts of concerned citizens to meet the primary needs of people (Gozum et al., 2021), such as food and hygiene essentials (del Castillo \& Maravilla, 2021).

Finally, there is the overarching principle of pakikipagkapwa-tao that pulls together all these Filipino values. In pakikipagkapwa-tao is the ultimate cultural value since it shapes an individual's shared identity where the self and the other become one (Sapitula, 2013). The primary basis for individuality, then, is not only in one's self-reflection, but also in one's regard for the other. Additionally, pakikipagkapwa-tao has a reflexive nature in the sense that what is good for oneself is good for the other and, therefore, shared; in parallel, what is detrimental for one is also accepted as detrimental for the other (Enriquez, 1992). Therefore, in the context of religious practices during the COVID-19 pandemic, pakikipagkapwa-tao can be understood as social distancing, as simply keeping a healthy and necessary separation between each other in order to avoid viral transmission. Filipinos have a high level of sensitivity to the quality and nature of their interpersonal relationships since much of their happiness and security come from these. They are a religious people. It is in their nature to desire to engage in religious practices as much as possible, while at the same time ensuring the observance of the two-metre separation, thereby helping curb the transmission of the virus. During the pandemic, the relationship between sarili, the self, and kapwa, the other, exists in an empty, "socially distanced", space. Paradoxically, it is this distance that connects the self with the other. It is in this empty space - that which is inherently intangible, but when shared becomes tangible-where pakikipagkapwa-tao lies.

Filipino culture and the Catholic faith are deeply intertwined. Even prior to the Christianization of the Philippines, early traditional Filipino religion practiced by natives shared similar religious constructs with Catholicism (del Castillo, 2015a, $2015 b$ ). The natives, however, were confronted with a foreign culture and religious 
tradition, giving way to the misappropriation of faith. To authentically send the message of the Gospel, "the Church [must establish] in such a way that it [the Gospel] makes sense to the people's local cultural context. It is necessary for Christianity to meet the people's deepest needs and penetrate their worldview" (F. A. del Castillo, 2015a, 2015b). Similarly, today, there is a need to recontextualize. Filipinos face the need to understand the importance of religious practices during the pandemic, while at the same time making sense of Filipino values in the current situation, for these values are in consonance with their Catholic faith.

The Filipino values of pagsasarili, pakikisama, pakikiramay, pagkakaisa and pakikipagkapwa-tao lead to an experience of kagandahang-loob, a culturally appropriated term referring to God's "gracious goodness" (de Mesa, 1988). From a Filipino lens, God's identity is revealed through a person's own kagandahang-loob, interpreted as the "goodness and benevolence that arises from the very core of one's personhood" (de Mesa, 1988). Filipinos have a high regard for the other, as evidenced by these values, since the kapwa, the other, reflects the goodness of God. Ultimately, there is nothing unique in how Filipinos find their values as motivations to do good, nor in how Filipinos faced the pandemic. What is to be pointed out, however, is that Filipino religious practices and Filipino values are so closely intertwined that an understanding of both, and their relationship, is necessary and crucial to a strong Filipino response to the COVID-19 pandemic.

\section{Conclusion}

The Philippine Catholic Church is well known for the grand festivities and mass gatherings. In some parishes in the country, different individuals devote themselves to daily Masses, rosary, and novenas. On Sundays, churches are known to be full since the faithful attend Mass together with their families as part of their Sunday obligations. However, the sudden outbreak of COVID-19 altered the way Catholics attend their usual expressions of their religiosity. Because of the ECQ, instead of participating in Holy Masses and other religious gatherings physically, they attend virtually through the aid of technology. Attending Masses, praying the rosary, and praying novenas are done through Facebook and YouTube live streams. In this manner, even though the faithful are in the comforts of their homes, they can still fulfil their obligation and devotion in their faith.

When the IATF shifted quarantine measures from ECQ-MGCQ, attending Masses physically was allowed but with strict restrictions on the number of attendees and implementation of safety measures. Parishes whose province is under MGCQ strictly followed and observed the safety protocols of IATF. This cooperation between the Philippine Catholic Church and the government was an avenue for both institutions to lessen the transmission of COVID-19. However, the question remains: with social distancing during religious practices, can Filipinos still have a grounded understanding of their values? Filipinos need to redeem their cultural values to re-appropriate the Christian values brought to them by their western colonizers, especially during the COVID-19 pandemic. It is through a recontextualization of these values that Filipinos are able to assert their cultural and religious identity. 
Due to the lockdown, Filipinos showed the value of pagsasarili. This is evident during the initial stages of the community quarantine wherein they relied solely on themselves. Even when attending religious celebrations, they are at home isolated from other people outside. Though this value seems selfish at first glance, it is really being selfless at the same time. Staying at home and isolating oneself from others is, therefore, the most morally responsible action so that one does not contribute to the spread of the coronavirus. Even as quarantine protocols relaxed, the value of pakikisama was proven by following the necessary health practices.

Apart from these, the Filipino value of pakikiramay was experienced during the pandemic. Pakikiramay was expressed through giving aid to the poor and the sick. The Philippine Catholic Church also showed this value when they provided programs to aid those who are greatly affected by the pandemic. These actions showed pakikiisa or unity among Filipinos. Also, the value of pakikipagkapwatao was proven strong by Filipinos since they became responsible towards one another during the pandemic. Social distancing, even though difficult at first, became the avenue for Filipinos to practice the value of pakikipagkapwa-tao. In attending Masses, following the safety measures and protocols before, during and after the mass is the Filipino expression of pakikipagkapwa-tao.

Lastly, these values are all rooted in the human person's kagandahang-loob, which is their innate goodness. As a country filled with people inclined towards religion, Filipinos showed their goodness during the pandemic by becoming responsible citizens. In these religious practices they participate in, Filipinos do their best to show their goodness by maintaining social distancing and following safety protocols. During the pandemic, the Filipinos highly manifest the values of pakikisama, pakikiramay and pagkakaisa not only through physical distancing, but also by concretely reaching out to those in need amidst the fear of infections. The religiosity of the people is a lived experience of God's kagandahang-loob.

This study analysed values that are deeply embedded in Filipino culture in order to recontextualize them. Even Filipinos who do not observe the health protocols and those who do not have the values under analysis in mind are still included in the recontextualization process. This interpretation and recontextualization of Filipino values are not accomplished only through positive evidence, but also by recognizing the negative, even contradicting, realities that permeate Filipino society. Looking at these values, one realizes how flexible and multidimensional they are in certain contexts or situations. The pandemic showed that Filipino values, no matter how distant people are with one another, will always be lived because they are at the core of every Filipino. Ultimately, in religious practices and values, Filipinos show that there is still hope amidst the pandemic.

Authors' Contribution All authors contributed to all aspects of the paper.

Funding No funding was received from this paper.

Declaration 
Conflict of Interest The authors declare no conflict of interest in this paper.

Ethical Statement The paper is compliant with ethical standard as it does not involve human or animal subjects.

\section{References}

Aguilar, K. (2021). Manila LGU suspends gov't work, classes in the city on Jan. 9. Philippine Daily Inquirer. Retrieved from https://newsinfo.inquirer.net/1381160/manila-lgu-suspends-govt-workclasses-in-the-city-on-jan-9.

Aguinaldo, M. (2002). A Study of Filipino Culture: The Devotion to the Black Nazarene of Quiapo. MMA Publications.

Attendance limited at Black Nazarene Masses in Philippines. (2021). Catholic News Agency. Retrieved from https://www.catholicnewsagency.com/news/attendance-limited-at-masses-for-feast-of-blacknazarene-2021-70452?fbclid=IwAR25EmCPVO201DeZX79eDbRoo-FmAHrMackd5zOLAXfNHZ dkZOwqykB-T5c.

Baker, J. O., Martí, G., Braunstein, R., Whitehead, A. L., \& Yukich, G. (2020). Religion in the age of social distancing: How COVID-19 presents new directions for research. Sociology of Religion, 81(4), 357-370. https://doi.org/10.1093/socrel/sraa039

Calleja, J. P. (2020a). Philippine gov't praises church pandemic efforts. Union of Catholic Asian News. Retrieved from https://www.ucanews.com/news/philippine-govt-praises-church-pandemic-efforts/ 87859\#.

Calleja, J. P. (2020b). Filipino faith perseveres despite pandemic restrictions. Union of Catholic Asian News. Retrieved from https://www.ucanews.com/news/filipino-faith-perseveres-despite-pandemicrestrictions/89718\#.

Carbayas, A. N., \& del Castillo, F. (2020). Christmas in the Philippines : Beyond popular religious tradition christmas in the Philippines : Beyond popular religious tradition. Asia Pacific Journal of Multidisciplinary Research, 8(2), 35-40.

Catholic Bishops' Conference of the Philippines. (1985). National Catechetical Directory of the Philippines (NCDP). Daughters of St. Paul.

Catholic Bishops' Conference of the Philippines. (1997). Catechism for Filipino Catholics (CFC). Word $\&$ Life Publications.

Catholic Bishops' Conference of the Philippines. (2007). New National Catechetical Directory of the Philippines (NNCDP). Manila: Catholic Bishops' Conference of the Philippines.

Chan, T., Michalak, N., \& Ybarra, O. (2019). When God is your only friend: Religious beliefs compensate for purpose in life in the socially disconnected. Journal of Personality, 87(3), 455-471. https:// doi.org/10.1111/jopy.12401

Cohen, S., Sherrod, D., \& Clark, M. (1986). Social skills and the stress-protective role of social support. Journal of Personality and Social Psychology, 50(5), 963-973.

Corpuz, J. C., \& Sarmiento, P. J. (2021). Going back to the basics: Experiencing Domus ecclesiae (House Church) in the celebration of the liturgy during COVID-19. Practical Theology, 14(1-2), 110-122. https://doi.org/10.1080/1756073X.2020.1841454

de Mesa, J. M. (1988). Re-Thinking the Faith with Indigenous Categories. Inter-Religio, 13(Summer), 18-29. Retrieved from http://nirc.nanzan-u.ac.jp/nfile/3366.

de Vera, B. (2020). 4.5 million Pinoys jobless in 2020. Philippine Daily Inquirer. Retrieved from https:// newsinfo.inquirer.net/1367928/4-5m-pinoys-jobless-in-2020.

del Castillo, F. (2015a). Christianization of the Philippines: revisiting the contributions of baroque churches and religious art. Mission Studies, 32(1), 47-65. https://doi.org/10.1163/15733831-12341 379

del Castillo, F. A. (2015). Gospel-culture relationship of traditional Filipino religion and Catholicism. The International Journal of Religion and Spirituality in Society. https://doi.org/10.13140/RG.2.1. 3208.2002

del Castillo, F., del Castillo, C. D., \& Corpuz, J. C. (2021). Dungaw: re-imagined religious expression in response to the COVID-19 pandemic. Journal of Religion and Health. https://doi.org/10.1007/ s10943-021-01266-X 
del Castillo, F., \& Maravilla, M. I. (2021). Community pantries: Their role in public health during the Covid-19 pandemic. Journal of Public Health. https://doi.org/10.1093/pubmed/fdab154

de la Costa, H. (1971). The Filipino National Tradition. In R. Paterno (Ed.), Horacio De La Costa S.J.: Selected Essays on the Filipino and His Problems Today. Quezon City: 2B3C Foundation, Inc., Philippine Province Society of Jesus, and Ateneo de Manila University.

Deopa, N., Forunato, P. (2020). Coronagraben. Culture and Social Distancing in Times of COVID-19. SSRN Electronic Journal, https://doi.org/10.2139/ssrn.3635287.

Durkheim, E. (1912). The Elementary Forms of the Religious Life. George Allen \& Unwin Ltd.

Elo, S., Kääriäinen, M., Kanste, O., Pölkki, T., Utriainen, K., \& Kyngäs, H. (2014). Qualitative Content Analysis: A Focus on Trustworthiness. SAGE Open, 4(1), 1-10. https://doi.org/10.1177/21582 44014522633

Enriquez, V. (1992). From Colonial to Liberation Psychology. University of the Philippines Press.

Esmaquel, P. (2020). Catholics in quarantine mark first online Holy Week. Rappler. Retrieved from https://www.rappler.com/nation/catholics-quarantine-online-holy-week-2020.

Finfgeld-Connett, D., \& Johnson, E. D. (2013). Literature search strategies for conducting knowledgebuilding and theory-generating qualitative systematic reviews. Journal of Advanced Nursing, 69(1), 194-204. https://doi.org/10.1111/j.1365-2648.2012.06037.x

Galang, J. R., Boleche, C., Jr., Braganza, B., Carreon, A., Garcia, A., Jr., Gopez, J. M., \& Quendan, R. (2018). Journeying through Religions, Religious Experiences and Spirituality (1st ed.). Books Atbp. Publishing Corp.

Glatz, C. (2020). Pope says living faith without sacraments, community is dangerous. Retrieved January 4, 2021, from National Catholic Reporter website: https://www.ncronline.org/news/vatican/francischronicles/pope-says-living-faith-without-sacraments-community-dangerous.

Gozum, I. E. (2020). The Filipino family in the formation of values in the light of John Paul II's Familiaris Consortio. Philosophia: An International Journal of Philosophy, 21, 561-577. https://doi.org/ 10.46992/pijp.21.si.a.18.

Gozum, I. E. A., Capulong, H. G. M., Gopez, J. M. W., \& Galang, J. R. F. (2021). Philippine community pantries as a way of helping the marginalized during the COVID-19 pandemic. Journal of Public Health. https://doi.org/10.1093/pubmed/fdab151

Guidaben, A. (2014). March of the multitudes: Nazarene procession grows every year. GMA News Online. Retrieved from https:/www.gmanetwork.com/news/news/nation/343106/march-of-themultitudes-nazarene-procession-grows-every-year/story/.

Jalea, G. (2021). EXPLAINER: What you need to know about the NCR Plus bubble. CNN Philippines. Retrieved from https://cnnphilippines.com/news/2021/3/22/Explainer-GCQ-bubble-NCR-plus.html? fbclid=IwAR0kJSSwj8ESRoLjqSaMtrmDI1_PbMhtaW10Njq3bZhZgKJPvSRXcbGLjDc.

James, W. (2004). The Varieties of Religious Experience. Routledge.

Koenig, H. (2012). Religion, spirituality, and health: The research and clinical implications. ISRN Psychiatry. https://doi.org/10.5402/2012/278730

Lagman, J. D., Vergara, R. J., \& Sarmiento, P. J. D. (2021). Culture as a contributory factor in combating the Covid-19 pandemic. Journal of Public Health, 43(2), e289-e290. https://doi.org/10.1093/ pubmed/fdaa280

Lanaria, L. (2014). Kapwa in Pamilya rooted in Loob of Divine Image: Thoughts from a Filipino Catholic Theologian. Religions: A Scholarly Journal https://doi.org/10.5339/rels.2014.family.14

Macaraan, W. E. R. (2019). A kapwa-infused paradigm in teaching Catholic theology/catechesis in a multireligious classroom in the Philippines. Teaching Theology and Religion, 22(2), 102-113. https:// doi.org/10.1111/teth. 12477

Manabat, A. (2020). 64th year feast of Virgen de los Remedios's coronation to push through sans devotees. Business Mirror. Retrieved from https://businessmirror.com.ph/2020/08/23/64th-year-feast-ofvirgen-de-los-remedioss-coronation-to-push-through-sans-devotees/.

Mayol, A. V., Mondragon, D. M. (2019). 1.5M devotees joined foot procession for Señor Sto. Niño; crowd 3 times bigger than last year. Cebu Daily News. Retrieved from https://cebudailynews.inquirer.net/213164/1-5m-devotees-joined-foot-proce ssion-for-senor-sto-nino-crowd-3-times-bigger-than-last-year.

Medina, M., Antonio, R. (2014). Pope John Paul II's visits to PH. Philippine Daily Inquirer. Retrieved from https://globalnation.inquirer.net/102782/pope-john-paul-iis-visits-to-ph.

Mendiola, R. (2018). 'Simbang Gabi' Gaining Popularity In Other Countries. Asian Journal. Retrieved from https://www.asianjournal.com/world/simbang-gabi-gaining-popularity-in-other-countries/. 
Meza, D. (2020). In a pandemic are we more religious? traditional practices of Catholics and the COVID-19 in Southwestern Colombia. International Journal of Latin American Religions, 4, 1-17. https://doi.org/10.1007/s41603-020-00108-0

Miller, B. (2005). The Anthropology of Culture (3rd ed.). Pearson Education South Asia Pte. Ltd.

Nuncio, R., Nuncio, E., \& Artuz, R. (2016). Praxis: Understanding Society, Culture and Politics. Books Atbp. Publishing Corp.

Ocampo, L., \& Yamagishi, K. (2020). Modeling the lockdown relaxation protocols of the Philippine government in response to the COVID-19 pandemic: An intuitionistic fuzzy DEMATEL analysis. Socio-Economic Planning Sciences. https://doi.org/10.1016/j.seps.2020.100911

Paje, P. M. I. (2014). Locating Filipino religious rituals online. CAS Review, 9(1), 21-41.

Pateña, A.J. (2018). Simbang Gabi: An enduring Filipino Christmas tradition. Philippine News Agency. Retrieved from https://www.pna.gov.ph/articles/1056699.

Patinio, F. (2021). Caritas Manila to give P10-M worth of GCs in NCR Plus. Philippine News Agency. Retrieved from https://www.pna.gov.ph/articles/1140656.

Philippine Church releases logo for 500 years of Christianity. (2019). Vatican News. Retrieved from https://www.vaticannews.va/en/church/news/2019-09/philipines-church-500-anniversary-celeb ration-logo.html.

Pullella, P., \& Francisco, R. (2015). Pope Manila Mass drew record crowd of 6-7 million: Vatican. Reuters. Retrieved from https://www.reuters.com/article/us-pope-philippines-idUSKBNOKQ 0TX20150118.

Reyes, R. C. (1985). Religious Experience in the Philippines: From Mythos through Logos Kairos. Philippine Studies, 33(2), 203-212. Retrieved from http://www.philippinestudies.net/ojs/index. $\mathrm{php} / \mathrm{ps} / \mathrm{article} / \mathrm{view} / 917$.

Santos, T.G. (2020). Website offers virtual "Visita Iglesia." Philippine Daily Inquirer. Retrieved from https://newsinfo.inquirer.net/1254863/website-offers-virtual-visita-iglesia.

Sapitula, M.V.J. (2013). Ang Pagiging Deboto Bilang Pakikipagkapwa: Isang Panimulang Pagsusuri sa mga Liham Pasasalamat ng mga Deboto ng Ina ng Laging Saklolo sa Baclaran. Daluyan: Journal Ng Wikang Filipino, 19(2), 111-132.

Sarmiento, P. J. D. (2021). Changing landscapes of death and burial practices: Public health response in time of COVID-19 pandemic. Journal of Public Health, 43(2), e267-e268. https://doi.org/10. 1093/pubmed/fdaa211

Sarmiento, P.J.D., Sibug, N.L., Lumanlan, P.T., Bonus, B.M., Samia, C.C. (2017). Pamagdarame in the Philippines: Forms, reasons, and preparations of Kapampangan flagellants. International Journal of Religion and Spirituality in Society, 7(3), 15-24. https://doi.org/10.18848/2154-8633/ CGP/v07i03/15-24

Singhal, T. (2020). A Review of Coronavirus Disease-2019 (COVID-19). The Indian Journal of Pediatrics, 87(4), 281-286. https://doi.org/10.1007/978-3-030-60188-1_2

Sirven, N., \& Debrand, T. (2008). Social participation and healthy ageing: An international comparison using SHARE data. Social Science \& Medicine, 67, 2017-2026.

Steptoe, A., Dockray, S., \& Wardle, J. (2009). Positive affect and psychobiological processes relevant to health. Journal of Personality, 77(6), 1747-1776.

Sulkowski, L., \& Ignatowski, G. (2020). Impact of COVID-19 Pandemic on Organization of Religious Behaviour in Different Christian Denominations in Poland. Religions, 11(5), 254. https://doi.org/ 10.3390/rel11050254.

Tewari, S., Khan, S., Hopkins, N., Srinivasan, N. (2012). Participation in Mass gatherings can benefit well-being: longitudinal and control data from a North Indian Hindu pilgrimage event. PLOS One, 7(10). https://doi.org/10.1371/journal.pone.0047291.

Thomas, A. (2017). Holy week traditions and activities in the Philippines. Balay.Ph. Retrieved from https://balay.ph/holy-week-in-the-philippines/.

Tiatco, A. P., \& Bonifacio-Ramolete, A. (2008). Cutud's ritual of nailing on the cross: Performance of pain and suffering. Asian Theatre Journal, 25(1), 58-76. https://doi.org/10.1353/atj.2008.0014

Valles, R. (2020). Recommendations and Guidelines for the Liturgical Celebration in 'New Normal' Condition. Retrieved from https://cbcpnews.net/cbcpnews/liturgical-guidelines-in-new-normalcondition/.

Wildman, W. J., Bulbulia, J., Sosis, R., \& Schjoedt, U. (2020). Religion and the COVID-19 pandemic. Religion, Brain and Behavior, 10(2), 115-117. https://doi.org/10.1080/2153599X.2020.1749339 
Wooden, C. (2020). Vatican approves special "Mass in the Time of Pandemic." National Catholic Reporter. Retrieved from https://www.ncronline.org/news/vatican/vatican-approves-special-masstime-pandemic.

World Health Organization. (2020). Practical considerations and recommendations for religious leaders and faith-based communities in the context of COVID-19. Retrieved from https://www.who.int/publi cations/i/item/practical-considerations-and-recommendations-for-religious-leaders-and-faith-basedcommunities-in-the-context-of-covid-19.

Publisher's Note Springer Nature remains neutral with regard to jurisdictional claims in published maps and institutional affiliations.

\section{Authors and Affiliations}

\section{Joseph Renus F. Galang ${ }^{1,2}$ (D) . Jose Ma W. Gopez ${ }^{3}$. Ivan Efreaim A. Gozum³ . Philip Joseph D. Sarmiento ${ }^{4}$}

Jose Ma W. Gopez

gopez.josema@auf.edu.ph

Ivan Efreaim A. Gozum

gozum.ivanefreaim@auf.edu.ph

Philip Joseph D. Sarmiento

pjsarmiento@hau.edu.ph

1 Theology and Religious Education Department, De La Salle University, 2401 Taft Ave, 0922 Manila, Philippines

2 Graduate School, Angeles University Foundation, Mac-Arthur Hi-Way, 2009 Angeles City, Philippines

3 Center for Christian Formation and Praxis, Angeles University Foundation, Mac-Arthur Hi-Way, 2009 Angeles City, Philippines

4 Christian Living Education Department, Holy Angel University, 1 Holy Angel Avenue, Sto. Rosario St., 2009 Angeles City, Philippines 